JURNAL PENDIDIKAN, p-ISSN 2715-095X, e-ISSN 2686-5041

Volume 29, No.3, Nopember 2020 (261-268)

Online: http://journal.univetbantara.ac.id/index.php/jp

\title{
Upaya Meningkatkan Prestasi Belajar IPS dengan Model Pembelajaran Kooperatif Tipe Student Teams Achievement Division (STAD) Bagi Siswa Kelas IXH Semester II SMP Negeri 4 Sukoharjo
}

\author{
Jamiyem \\ Guru SMP Negeri 4 Sukoharjo, Email: jamiyem67@gmail.com
}

\begin{abstract}
Abstrak: Penelitian ini bertujuan untuk meningkatkan prestasi belajarr IPS melalui model pembelajaran kooperatif tipe STAD pada siswa kelas IXH SMP Negeri 4 Sukoharjo tahun pelajaran 2017/2018. Subjek penelitian tindakan kelas ini adalah siswa kelas IXH SMP Negeri 4 Sukoharjo tahun pelajaran 2017/2018 sebanyak 32 siswa yang terdiri dari 14 siswa laki-laki dan 18 siswa perempuan, sebagai subjek penerima tindakan, sedangkan untuk subjek pelaku tindakan adalah guru IPS kelas IXH selaku guru, teman sejawat selaku subjek yang melakukan observasi proses pembelajaran, Kepala Sekolah selaku subjek sumber data. Metode pengumpulan data dilakukan melalui teknik tes, observasi dan dokumentasi. Penelitian Tindakan ini dilakukan dalam dua siklus, tiap-tiap siklus terdiri dari: perencanaan, tindakan, pengamatan dan refleksi. Hasil penelitian ini menunjukkan bahwa penggunaan model pembelajaran kooperatif tipe STAD dapat meningkatkan prestasi belajarr IPS siswa kelas IXH SMP Negeri 4 Sukoharjo tahun pelajaran 2017/2018. Hal ini dapat dilihat dari nilai rata-rata prestasi belajar IPS siswa juga mengalami peningkatan yaitu sebelum tindakan sebesar 70,3, pada siklus I sebesar 77,5 dan pada siklus II sebesar 82,5. Selain itu, presentase ketuntasan belajar siswa, yaitu sebelum tindakan sebesar $43,75 \%$, pada siklus I sebesar $72 \%$ dan pada siklus II sebesar $94 \%$..
\end{abstract}

Kata-kata Kunci: Pembelajaran kooperatif tipe Student Teams Achievement Divisions (STAD)dan prestasi belajarr IPS siswa.

\section{Social Science Learning Outcome Effort of IXH Students of SMP Negeri 4 Sukoharjo By Means of Applying Cooperative Learning Model Type STAD}

\author{
Jamiyem \\ The Teacher of SMP Negeri 4 Sukoharjo,Email:jamiyem67@gmail.com
}

\begin{abstract}
The aim of this research is to improve social science learning outcome of IXH students of SMP Negeri 4 Sukoharjo at academic year 2017/2018 by means of applying cooperative learning model type STAD. This research is a classroom action research which was conducted in two cycles. The subject of this research is the IXH students with total number of 32 students consisting of 14 male students and 18 female students. This research is conducted by the social science teacher of IXH, other social science teacher as colleague who observes the learning process, and the Headmaster as subject to source of the data. The method of collecting data is conducted by test technique, observation and documentation. This classroom action research is conducted in two cycles, each of which consisting of four stages namely, planning, implementation, observation and reflection. The result of data analysis shows that by means of applying cooperative learning model type STAD there is an improvement of the social science learning outcome of IXH students of SMP Negeri 4 Sukoharjo at academic year 2017/2018. There is an improvement of the learning outcome average: 70.3 before the
\end{abstract}


research, $77.5 \%$ after first cycle and 82.3 after the second cycle. Besides, the classical completeness average is also improved: $43.75 \%$ before the research, $72 \%$ after first cycle, and $94 \%$ after the second cycle.

Key word: STAD cooperative learning model type and social science learning outcomes

\section{Pendahuluan}

Pembelajaran IPS di SMP/ MTs, salah satutujuannya adalah memiliki kemampuan dasar untuk berpikir logis dan kritis, rasa ingin tahu, inquiri, memechkan masalah, dan keterampiran dalam kehidupan sosial.Untuk mencapai tujuan tersebut memang tidaklah mudah. Pelaksanaan pembelajaran IPS di SMP Negeri 4 Sukoharjo masih kurang efektif dan efisien, hal ini tercermin dari rendahnya prestasi siswa. Berdasarkan hasil ulangan harian terprogram semester gasal kelas IX HSMP Negeri 4 Sukoharjo masih belum sesuai harapan, yaitu sebagian siswa belum tuntas belajar. Kriteria Ketuntasan Belajar (KKM) untuk SMP Negeri 4 Sukoharjo tahun pelajaran 2017/2018 pada mata pelajaran IPS kelas IX adalah siswa dapat mencapai skor minimal 75 untuk suatu kompetensi dasar atau siswa menguasai minimal $75 \%$ dari seluruh materi yang berkaitan dengan kompetensi dasar tertentu. Di SMP Negeri 4 Sukoharjo hasil nilai ulangan semester genap tahun pelajaran 2017/2018 pada pelajaran IPS materi Kerjasama Ekonomi Internasional kelas IX H memperoleh nilai rata-rata 64,19 dengan persentase siswa yang tuntas hanya $16,7 \%$ atau sebanyak 5 siswa dari jumlah siswa 30 orang. Rendahnya hasil ulangan harian semester gasal tersebut merupakan suatu indikasi bahwa penguasaan materi IPS siswa masih rendah. Melihat kurangnya pemahaman siswa terhadap suatu kompetensi dasar adalah guru kurang menerapkan model-model pembelajaran aktif, siswa kurang aktif dalam berlangsungnya proses belajar mengajar,serta membuat siswa beranggapan mata pelajaran IPS merupakan pelajaran yang sulit. Metode pembelajaran yang diterapkan oleh guru sebelumnya yaitu metode konvensional atau pembelajaran langsung yang disertai dengan latihan soal,hal tersebut kurang aktif, variatif dan menarik serta kurang melibatkan aktivitas siswa maupun tanggung jawab siswa baik secara individual maupun kelompok siswa merasa sulit memahami materi, tetapi siswa merasa kurang percaya diri atau takut untuk bertanya, sehingga prestasi belajarrnya rendah. Menurut Gage dalam Sagala (2003 : 13), belajar adalah sebagai suatu proses dimana suatu organism berubah perilakunya sebagai akibat dari pengalaman.Menurut Nichol dalam Aunurrahman (2009 :37), belajar merupakan kegiatan penting setiap orang, termasuk didalamnya belajar bagaimana seharusnya belajar.Prestasi belajarr ditandai dengan perubahan tingkah laku. Walaupun tidak semua perubahan tingkah laku merupakan prestasi belajarr, akan tetapi aktivitas belajar umumnya disertai perubahan tingkah laku. Untuk meningkatkan prestasi belajarr siswa, dibutuhkan sebuah proses kreatif dalam pembelajaran, yakni upaya-upaya penting yang digunakan untuk mengaktifkan siswa.Menurut Slavin (2005 : 143), STAD merupakan salah satu metode pembelajaran kooperatif yang paling sederhana, dan merupakan model yang paling baik untuk permulaan bagi para guru yang baru menggunakan pendekatan kooperatif, dan STAD terdiri dari lima komponen utama, yaitu presentasi kelas, tim, kuis, skor kemajuan individual, dan rekognisi tim. Dengan menggunakan model pembelajaran kooperatif tipe Student Teams Achievement Division (STAD) pada materi Kerjasama Ekonomi Internasional kelas IX HSMP Negeri 4 Sukoharjo, dimana siswa akan belajar dalam kelompok-kelompok kecil 
dan saling membantu satu sama lain. Kelas disusun dalam beberapa kelompok yang tiap kelompok terdiri dari empat sampai enam siswa dengan kemampuan yang heterogen.

Hal ini bermanfaat untuk melatih siswa menerima perbedaan pendapat dan bekerja sama dengan temanyang latar belakangnya berbeda. Pada model pembelajaran kooperatif diajarkan ketrampilan-ketrampilan khusus agar dapat bekerja sama dengan baik di dalam kelompoknya. Langkah-langkah pembelajaran kooperatif tipe STAD ini didasarkan pada langkah-langkah kooperatif yang terdiri atas 6 langkah atau fase. Fase-fase dalam pembelajaran ini seperti disajikan dalam tabel berikut.

Tabel 1.Fase-fase Pembelajaran Kooperatif Tipe STAD

\begin{tabular}{|c|c|}
\hline Fase & Kegiatan Guru \\
\hline \multicolumn{2}{|l|}{ Fase 1} \\
\hline $\begin{array}{l}\text { Menyampaikan tujuan dan memotivasi } \\
\text { siswa }\end{array}$ & $\begin{array}{l}\text { Menyampaikan semua tujuan } \\
\text { pembelajaran yang ingin dicapai pada } \\
\text { pembelajaran tersebut dan memotivasi } \\
\text { siswa belajar. }\end{array}$ \\
\hline \multicolumn{2}{|l|}{ Fase 2} \\
\hline Menyajikan/menyampaikan informasi & $\begin{array}{l}\text { Menyajikan informasi kepada siswa } \\
\text { dengan jalan mendemonstrasikan atau } \\
\text { lewat bahan bacaan. }\end{array}$ \\
\hline \multicolumn{2}{|l|}{ Fase 3} \\
\hline $\begin{array}{l}\text { Mengorganisasikan siswa dalam } \\
\text { kelompok-kelompok belajar }\end{array}$ & $\begin{array}{l}\text { Menjelaskan kepada siswa bagaimana } \\
\text { caranya membentuk kelompok belajar } \\
\text { dan membantu setiap kelompok agar } \\
\text { melakukan transisi secara efisien. }\end{array}$ \\
\hline \multicolumn{2}{|l|}{ Fase 4} \\
\hline $\begin{array}{l}\text { Membimbing kelompok bekerja dan } \\
\text { belajar }\end{array}$ & $\begin{array}{l}\text { Membimbing kelompok-kelompok } \\
\text { belajar pada saat mereka mengerjakan } \\
\text { tugas mereka. }\end{array}$ \\
\hline \multicolumn{2}{|l|}{ Fase 5} \\
\hline Evaluasi & $\begin{array}{l}\text { Mengevaluasi prestasi belajarr tentang } \\
\text { materi yang telah diajarkan atau } \\
\text { masing-masing kelompok } \\
\text { mempresentasikan hasil kerjanya. }\end{array}$ \\
\hline \multicolumn{2}{|l|}{ Fase 6} \\
\hline Memberikan penghargaan & $\begin{array}{l}\text { Mencari cara-cara untuk menghargai } \\
\text { baik upaya maupun prestasi belajarr } \\
\text { individu dan kelompok. }\end{array}$ \\
\hline
\end{tabular}

Berdasarkan uraian di atas, dapat dirumuskan tujuan penelitian ini adalah untuk meningkatkan prestasi belajarr IPS melalui model pembelajaran kooperatif tipe STAD pada siswa kelas IX HSMP Negeri 4 Sukoharjo tahun pelajaran 2017/2018.

\section{Metode Penelitian}

Penelitian ini adalah Penelitian Tindakan Kelas (PTK), merupakan suatu pencermatan terhadap kegiatan yang sengaja dimunculkan, dan terjadi dalam sebuah kelas (Arikunto, 2010: 130). Penelitian ini dilaksanakan di SMP Negeri 2 Sukoharjo. Tahaptahap pelaksanaan kegiatan dilakukan selama kurang lebih lima bulan yaitu sejak bulan Januari sampai dengan bulan Mei 2017. Subjek penelitian tindakan kelas ini adalah siswa kelas IX HSMP Negeri 4 Sukoharjo semester II tahun pelajaran 2017/2018 sebanyak 32 
siswa yang terdiri dari 14 siswa laki-laki dan 18 siswa perempuan, sebagai subjek penerima tindakan, sedangkan untuk subjek pelaku tindakan adalah guru IPS kelas IX H selaku guru, teman sejawat selaku subjek yang melakukan observasi proses pembelajaran, Kepala Sekolah selaku subjek sumber data.Metode pengumpulan data dilakukan melalui teknik tes, observasi dan dokumentasi. Teknik pengumpulan data yang digunakan adalah: (a) Tes, observasi, dan dokumentasi. Metode tes digunakan untuk memperoleh data tentang prestasi belajarr IPS siswa sebelum penelitian, selama penelitian dan setelah penelitian dilaksanakan. Observasi yang digunakan adalah observasi sistematis, yaitu observasi yang dilakukan oleh pengamat dengan menggunakan pedoman sebagai instrumen pengamatan. Instrumen yang digunakan dalam penelitian ini adalah: lembar observasi, tes, dan dokumentasi. Lembar observasi dugunakan peneliti sebagai pedoman melakukan observasi atau pengamatan guna memperoleh data yang akurat dalam pengamatan. Lembar observasi juga digunakan untuk memonitor dan mengevaluasi setiap tindakan agar kegiatan observasi tidak terlepas dari konteks permasalahan dan tujuan penelitian. Tes digunakan untuk melihat seberapa besar penguasaan konsep IPS siswa terhadap materi yang diajarkan.Hasil tes dianalisis guna mengetahui penguasaan materi IPS setelah dilakukan model pembelajaran STAD. Indikator keberhasilan dalam penelitian ini adalah apabila nilai ratarata tes siswa sekurang-kurangnya 80,0 dan banyak siswa dengan nilai di atas batas ketuntasan minimal (KKM) yaitu $\geq 75,0$ mencapai $\geq 90 \%$.

\section{Hasil Penelitian}

Berdasarkan hasil pretest,dari 32siswa yang mencapai nilai kriteria ketuntasan minimal (KKM) yaitu 75 sebanyak 14 siswa (43,75\%) dan siswa yang tidak mencapai nilai kriteria ketuntasan minimal (KKM) sebanyak18 siswa $(66,25 \%)$ dengan nilai rata-rata kelas sebesar 70,3. Guru hanya menerapkan model ceramah dan siswa hanya disuruh mendengarkan dan mencatat apa yang diperlukan. Hasil ini dapat ditampilkan pada grafik berikut.

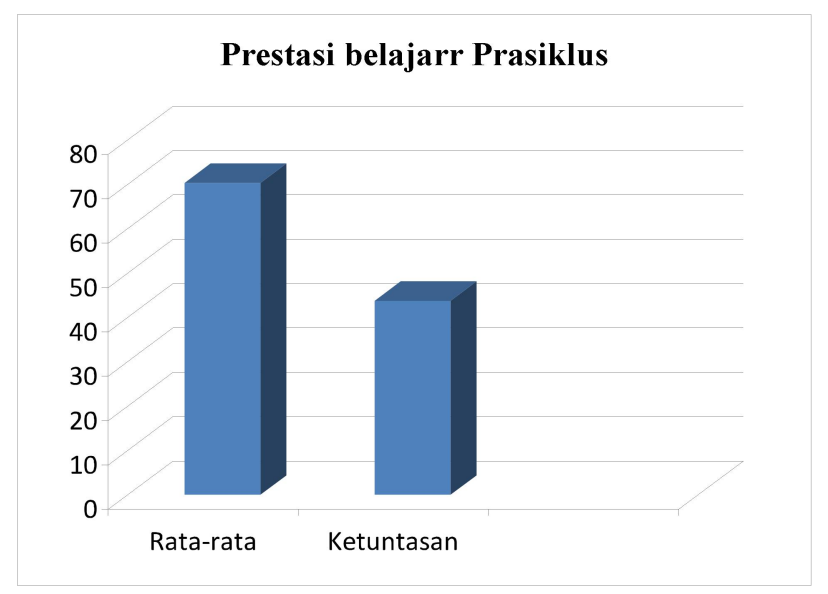

Gambar 1. Grafik Prestasi belajarr IPS Siswa pada Prasiklus

Salah satu solusi yang dikembangkan adalah penggunaan model pembelajaran kooperatif tipe STAD. Dengan penggunaan model pembelajaran tersebut diharapkan akan menciptakan suasana belajar yang berbeda, bervariasi dan menyenangkan sehingga dapat 
menarikperhatian siswa dan meningkatkan prestasi belajar siswa. Tindakan Siklus I, Pembelajaran dilaksanakan dengan pedoman Rencana Perbaikan Pembelajaran (RPP) selama 2 jam pelajaran ( 2 x 40 menit). Kompetensi Dasar yang disampaikan pada siklus I adalah Mendeskripsikan Kerjasama Antar negara di Bidang Ekonomi.Setelah langkah apersepsi dilanjutkan dengan penyampaian materi dengan model pembelajaran tipe STAD.

Model pembelajaran tipe STAD dilaksanakan dengan menggunakan langkahlangkah sebagai berikut: (1) Pendahuluan berisi kegiatan guru memberi salam, mengkondisikan kelas, dan mengecek presensi siswa. Guru menyampaikan tujuan pembelajaran yang ingin dicapai dan memberi motivasi belajar; (2) Kegiatan inti tentang pelaksanaan kegiatan modelpembelajaran kooperatif tipe STAD sebagai berikut: (a) Guru membagi siswa menjadi 5 kelompok, tiap kelompok beranggotakan 6siswa, (b) Guru memberikan contoh materi dan memberikan soal yang berkaitan dengan pengertian dan bentuk kerja sama Internasional yang harus dipecahkan bersama kepada setiap kelompok, (c) Guru meminta siswa untuk berdiskusi tentang soal pengertian dan bentuk kerja sama Internasional, (d) Setelah selesai berdiskusi, guru meminta salah satu anggota dari kelompok 1-5 untuk maju ke depan kelas untuk presentasi, dengan cara ditunjuk guru secara acak dari nomer absen siswa, (e) Karena perwakilan dari kelompok 1-5 sudah presentasi di depan kelas, maka guru bersama siswa menyimpulkan kegiatan pembelajaran yang telah dilakukan; (3) Penutup, berisi kegiatan guru memberikan kesempatan siswa untuk menanyakan hal-hal yang kurang jelas. Kemudian guru memberikan postest, dan memberikan tugas rumah. Hasil observasi menunjukkan bahwa guru telah melaksanakan kegiatan pembelajaran dengan cukup baik, yaitu guru mengajar dengan arah dan tujuan yang jelas.

Namun ketika guru menyampaikan materi denganmodel pembelajaran kooperatif tipe STAD, beberapa siswa tampak masih kurang memperhatikan, dan beraktivitas sendiri.Selain itu tidak semua kelompok dapat berdiskusi dengan baik. Berdasarkan hasil evaluasi pada siklus I menunjukkan adanya peningkatanprestasi belajarr siswa. Rata-rata prestasi belajarr siswa pada siklus I adalah 77,5, sebanyak 23siswa (72\%) mencapai nilai kriteria ketuntasan minimal (KKM), dan sebanyak 9 siswa (28\%) tidak mencapai nilai KKM.Berdasarkan hasil tersebut dapat diketahui bahwa proses pembelajaran pada siklus pertama sudah meningkatkan prestasi belajarr tetapi belum berjalan dengan cukup baik serta belum mencapai indikator kinerja yang diharapkan. Hasil ini dapat ditampilkan pada grafik berikut.

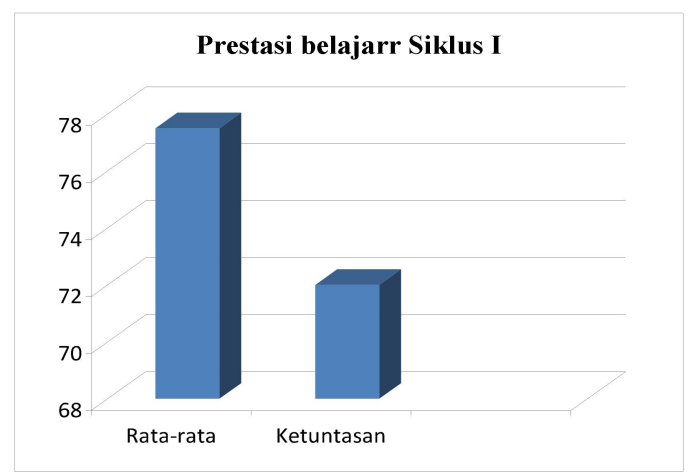

Gambar 2. Grafik Prestasi belajarr IPS Siswa pada Siklus I 
Keberhasilan yang dicapai setelah siklus I hanya sebagian siswa yang menunjukkan partisipasi yang meningkat sementara siswa lainnya masih pasif. Refleksi terhadap faktorfaktor yang menjadi penyebab kurangnya partisipasi siswa adalah: (1) Sebagian siswa belum bisa mengikuti langkah-langkah pembelajaran model pembelajaran kooperatif tipe STAD; (2) Kerjasama dalam kelompok berdiskusi belum maksimal; (3) Hanya siswa tertentu saja yang dapat memahami materi dan soal yang diberikan kepada setiap kelompok.

Tindakan Siklus II, Pembelajaran dilaksanakan dengan pedoman Rencana Perbaikan Pembelajaran (RPP) selama 2 jam pelajaran ( 2 x 40 menit). Kompetensi Dasar yang disampaikan pada siklus II adalah Mengidentifikasi Dampak Kerjasama AntarNegara terhadap Perekonomian Indonesia.Setelah langkah apersepsi dilanjutkan dengan penyampaian materi dengan model pembelajaran tipe STAD.Pada pelaksanaan siklus II ini, kegiatan pembelajaran dilaksanakan dengan proses sebagai berikut. (1) Guru mengulang sekilas materi yang telah disampaikan kemudian melanjutkan materi yang baru dengan model pembelajaran kooperatif tipe STADseperti pada siklus I, tetapi jumlah anggota kelompok 4-5 siswa, dan guru melakukan tanya jawab dengan siswa; (2) Guru memberikan latihan soal-soal dengan model pembelajaran kooperatif tipe STAD bagaimana cara memahami materi Dampak Kerjasama AntarNegara terhadap Perekonomian Indonesia; (3) Guru memberikan kesempatan kepada siswa untuk mengerjakan latihan-latihan di whiteboard dan menjelaskannya kepada siswa yang lain dengan pantauan guru sampai semua siswa mengerti; (4) Guru bersama siswa menyimpulkan kegiatan pembelajaran yang telah dilakukan; (5) Guru memberikan kesempatan kepada siswa untuk menanyakan hal-hal yang kurang jelas; (6) Guru memberikan postest dan tugas rumah. Berdasarkan kegiatan observasi, secara garis besar diperoleh gambaran pelaksanaan tindakan siklus II ada peningkatan prestasi belajarr siswa. Dalam pertemuan ini banyak siswa mampu menjawab soal-soal yang diberikan dengan benar dan baik. Sebagian siswa aktif dalam bertanya dan mengemukakan ide mereka. Siswa juga dapat memahami materi yang telah diajarkan hal ini terlihat dari cara siswa menyelesaikan soal-soal.

Berdasarkan hasil evaluasi pada siklus II menunjukkan adanya peningkatan hasilbelajar siswa. Rata-rata prestasi belajarr siswa pada siklus II adalah 81,2, sebanyak 28 siswa $(93,3 \%)$ mencapai nilai kriteria ketuntasan minimal (KKM), dan sebanyak 2 siswa $(6,7 \%)$ tidak mencapai nilai KKM. Hasil ini dapat ditampilkan pada grafik berikut.

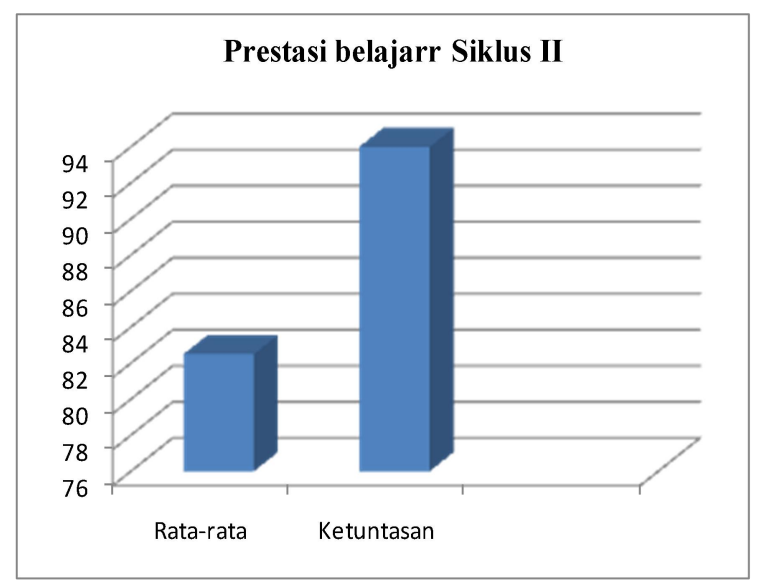

Gambar 3. Grafik Prestasi belajar IPS Siswa pada Siklus II 
Sebagian siswa menunjukkan partisipasinya meningkat dari siklus II.Keberhasilan yang dicapai setelah siklus II telah memenuhi indikator keberhasilan penelitian ini, sehingga tindakan ini tidak diteruskan atau dihentikan pada siklus II.

\section{Pembahasan}

Berdasarkan pengolahan dan analisis data di atas, maka diperoleh interpretasi bahwa penerapan model pembelajaran kooperatif tipe STAD terhadap peningkatan prestasi belajarr siswa menunjukkan bahwa terjadi peningkatan prestasi belajarr siswa pada sebelum tindakan siklus I, dan pada siklus I ke siklus II. Terjadi peningkatan prestasi belajarr siswa ini sebagai efek dari meningkatkan keterampilan sosial dan kemandirian siswa yaitu adanya perhatiaan siswa dalam proses belajar, kerjasama dalam tiap pasangan kelompok dan kemandirian dalam mengerjakan soal. Hal ini dapat dilihat dari hasil penelitian dari siklus pertama sampai dengan siklus ketiga dapat diringkaskan seperti terlihat pada tabel sebagai berikut:

\begin{tabular}{lllll}
\multicolumn{5}{c}{ Tabel 2. Profil Kelas Sebelum dan Sesudah Tindakan Penelitian } \\
\hline No & Hasil Siswa & Kondisi Awal & Siklus I & Siklus II \\
1 & Nilai rata-rata & 70,3 & 77,5 & 82,5 \\
2 & Siswa yang tuntas KKM & 14 siswa & 23 siswa & 30 siswa \\
& & $(43,75 \%)$ & $(72 \%)$ & $(94 \%)$ \\
\hline
\end{tabular}

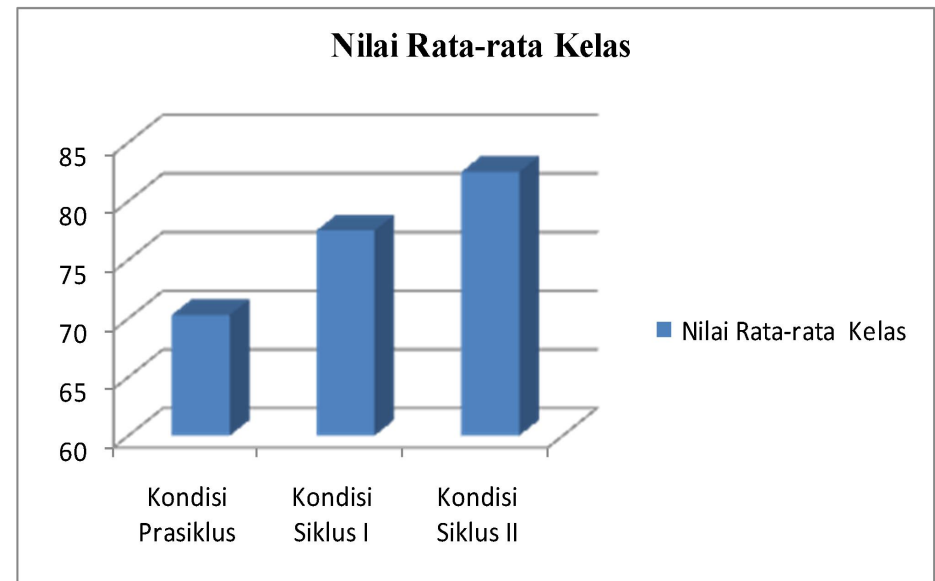

Gambar 4. Grafik Hasil Peningkatan Rata-Rata Prestasi belajarr IPS Siswa

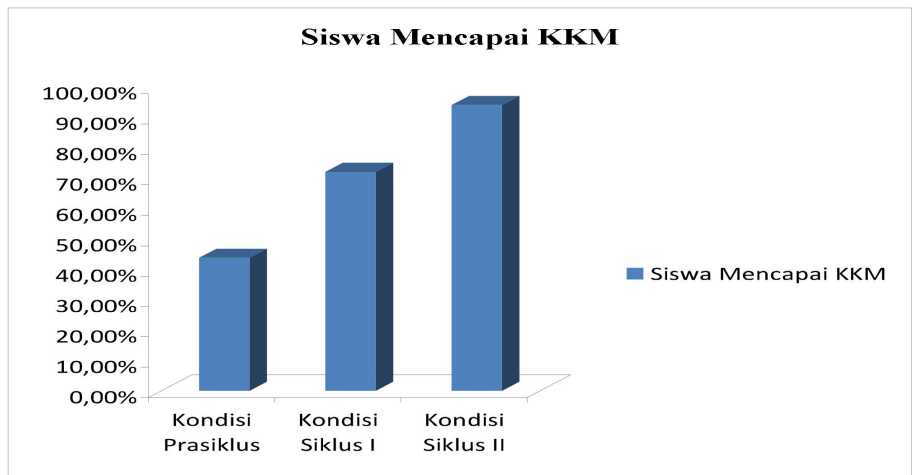

Gambar 5. Grafik Hasil Peningkatan Ketuntasan Prestasi belajarr IPS Siswa Dari tabel dan grafik di atas dapat disimpulkan bahwa prestasi belajarr IPSsiswa dengan menerapkan model pembelajaran kooperatif tipe STAD di setiap putaran mengalami 
peningkatan, yaitu: (1) Sebelum dilakukan tindakan, nilai rata-rata prestasi belajarrsiswa adalah 70,3 sedangkan persentase ketuntasan 43,75\%; (2) Setelah dilakukan tindakan pada siklus I, nilai rata-rata prestasi belajarrIPS siswa mengalami peningkatan yaitu 77,5 dengan persentase ketuntasan 72\%, tetapi belum mencapai indikator yang diharapkan; (3) Pada siklus II, nilai prestasi belajarr siswa meningkat yaitu menjadi 82,5 dengan persentase ketuntasan sebesar 94\%dan sudah mencapai indikator yang diharapkan maka penelitian tindakan kelas ini sudah berhasil. Rata-rataprestasi belajarrIPS siswa pada siklus IIsebesar $82,5 \geq 80,0$ (indikator kinerja) dan persentase ketuntasan siklus II sebesar $94 \% \geq 90 \%$ (indikator kinerja). Jadi, indikator kinerja sudah tercapai sehingga tidak dilanjutkan ke siklus berikutnya.

\section{Simpulan dan Saran}

Penggunaan model pembelajaran kooperatif tipe STAD dapat meningkatkan prestasi belajarr IPS siswa kelas IX HSMP Negeri 4 Sukoharjotahun pelajaran2017/ 2018. Hasil penelitian ini menunjukkan adanya peningkatan pada hasil balajar IPS siswa. Hal ini dapat dilihat dari nilai rata-rata prestasi belajarr IPS siswa juga mengalami peningkatanyaitu sebelum tindakan sebesar 70,3, pada siklus I sebesar 77,5 dan pada siklus II sebesar 82,5.Selain itu, presentase ketuntasan belajar siswa, yaitu sebelum tindakan sebesar $43,75 \%$, pada siklus I sebesar $72 \%$ dan pada siklus II sebesar $94 \%$.

\section{Daftar Rujukan}

Abdurrahman, M. (2003). Pendidikan Bagi Anak Berkesulitan Belajar. Jakarta: Rineka Cipta.

Aqib, Z. (2009). Penelitian Tindakan Kelas untuk Guru.Bandung: Yrama Widya.

Arikunto, S. (2006). Prosedur Penelitian Suatu Pendekatan Praktik (Edisi Revisi VI). Jakarta: Rineka Cipta.

Aunurrahman. (2009). Belajar dan Pembelajaran. Bandung:Alfabeta.

Hadi, S. (2006). Aplikasi IPS. Bogor: Yudhistira.

Sagala, S. (2003). Konsep dan Makna Pembelajaran. Bandung: Alfabeta.

Slameto. (2003). Belajar Dan Faktor-Faktor Yang Mempengaruhinya. Jakarta: Rineka Cipta.

Slavin, R. (2005). Cooperative Learning. Bandung: Nusa Media.

Sudjana, N. (2005). Dasar-dasar Proses Belajar Mengajar. Jakarta: Sinar Baru Algensido. 